\title{
Influence of environmental factors on the bathymetric distribution of the flecked box crab Hepatus pudibundus (Herbst, 1785) (Crustacea: Aethroidea) in the Southeastern Brazilian coast
}

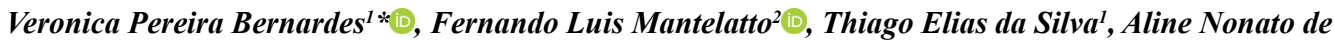 \\ Sousa ${ }^{1}$, Camila Hipólito Bernardo ${ }^{1} \mathbb{D}$ \& Adilson Fransozo ${ }^{1}$ \\ ${ }^{1}$ Universidade Estadual Paulista, Instituto de Biociências, Departamento de Zoologia, Botucatu, SP, Brasil \\ ${ }^{2}$ Universidade de São Paulo, Faculdade de Filosofia, Ciências e Letras de Ribeirão Preto, Departamento de \\ Biologia, Laboratório de Bioecologia e Sistemática de Crustáceos, Ribeirão Preto, SP, Brasil \\ *Corresponding author: Veronica Pereira Bernardes, e-mail: vebernardes@gmail.com \\ BERNARDES, V.P., MANTELATTO, F.L., SILVA, T.E., SOUSA, A.N., BERNARDO, C.H., FRANSOZO, A. \\ Influence of environmental factors on the bathymetric distribution of the flecked box crab Hepatus pudibundus \\ (Herbst, 1785) (Crustacea: Aethroidea) in the Southeastern Brazilian coast. Biota Neotropica. 19(1): e20180549. \\ http://dx.doi.org/10.1590/1676-0611-BN-2018-0549
}

\begin{abstract}
This study evaluated the relationships between environmental factors and the spatio-temporal distribution of $H$. pudibundus, with the hypothesis of differential occupation in coastal areas of southeastern Brazil. The samplings took place monthly in January-December 2000 period, along nine transects from 2 to $40 \mathrm{~m}$ of depth, in Ubatuba region, northern coast of São Paulo. We collected 1808 individuals of $H$. pudibundus. The highest abundance was recorded in winter in the transects 10-25 m deep. Abundance was positively correlated with organic matter content and texture sediment (phi values). With the retreat of the South Atlantic Central Water (SACW) in autumn and winter, the sediment swirls, suspending the detritivore and filter-feeding macrofauna, increasing the food availability. Sites characterized by finer sediment offer higher food availability, besides facilitating $H$. pudibundus burying behavior. Due to its opportunistic predatory behavior, this species feeds on a variety of organisms, including mollusks, annelids and foraminifera, which are preys more abundant in the studied area and in sediments of finer grain size.
\end{abstract}

Keywords: Brachyura, sediment texture, Decapoda, distribution, Coastal Water.

\section{Influência de fatores ambientais na distribuição batimétrica do caranguejo de baú Hepatus pudibundus (Herbst, 1785) (Crustacea: Aethroidea) na costa sudeste do Brasil}

Resumo: Este estudo avaliou as relações dos fatores ambientais e a distribuição espaço-temporal de H. pudibundus, com a hipótese de ocupação diferencial em uma região do litoral sudeste do Brasil. As amostragens ocorreram mensalmente no período de janeiro a dezembro de 2000, ao longo de nove transectos de 2 a $40 \mathrm{~m}$ de profundidade, na região de Ubatuba, litoral norte de São Paulo. Foram coletados 1808 indivíduos de $H$. pudibundus. A maior abundância foi registrada no inverno nos transectos 10 a $25 \mathrm{~m}$ de profundidade. A abundância foi positivamente correlacionada com o teor de matéria orgânica e a textura do sedimento (valores de phi). Durante o outono e inverno com a retração da ACAS ocorre o revolvimento do sedimento e a supensão da macrofauna detritívora e filtradora, aumentando a disponibilidade de alimento. Locais caracterizados por sedimentos mais finos oferecem maior disponibilidade de alimentos, além de facilitar o comportamento de H. pudibundus se enterrar. Devido ao comportamento predatório oportunista, esta espécie se alimenta de uma grande variedade de organismos, incluindo moluscos, anelídeos e foraminíferos, que são as presas mais abundantes nas áreas estudadas, principalmente em locais com grãos menores.

Palavras-chave: Brachyura, textura do sedimento, Decapoda, distribuição, Água Costeira. 


\section{Introduction}

Marine resources and their benefits to mankind are still poorly known and, therefore, still being studied. Small, sheltered coastal areas, such as bays and inlets, provide conditions for the establishment of several species with different ecological profiles. Some of these species are of economic interest and/or key elements in the trophic webs (Mantelatto et al. 1995a, Bertini \& Fransozo 1999, Fransozo et al. 2016, Mantelatto et al. 2016). Considering that these coastal areas are naturally influenced by environmental factors, and given their reasonable sizes, they can be studied in more detail and serve as models for extend the understanding of human and/or natural impacts in larger scales. The northern coast of São Paulo has been affected by an increasing tourism and urbanization pressure (Burone \& Pires-Vanin 2006, Gallo-Junior et al. 2011). In addition, trawling fisheries are intense, they affect the sedimentation processes, lead to overfishing, and disturbance of benthic communities (Pires-Vanin 1993, Mantelatto et al. 2016). Trawling is a non-selective activity, and many species of little or none economic value are captured as bycatch (Hall et al. 2000).

To better understand the distribution and abundance of a given species it is necessary to know details on its life-history, resource use patterns, and intra- and interspecific relationships, as well as its responses to environmental conditions. Thus, the study of variation of population structure in relation to environmental conditions may contribute to elucidate the factors that regulate abundance and distribution (Begon et al. 2006).

The distribution pattern of marine organisms may vary with local environmental conditions and lead to a differential spatial distribution (Bertini et al. 2010). Characteristics such as sediment texture and organic matter content, and water temperature and salinity, are important factors regulating the distribution and ecological relationships of benthic organisms, including decapod crustaceans. These factors control local marine productivity and environmental conditions, which in turn determine species' occurrence (Buchanan \& Stoner 1988, Lima et al. 2014a, Andrade et al. 2015, Bernardes et al. 2016).

The flecked box crab species Hepatus pudibundus (Herbst, 1785) is found in both sides of the Atlantic: on the western side, in Georgia (U.S.A.), Gulf of Mexico, Antilles, Venezuela, Guyana, and Brazil (Melo 1996), and on the eastern side, from Guinea down to South Africa. This species belongs to superfamily Aethroidea, which includes six genera ( $\mathrm{Ng}$ et al. 2008). Two of which occurring in Brazil: Hepatus Latreille, 1802 and Osachila Stimpson, 1871 (Melo 1996). In Ubatuba, H. pudibundus is the second or third most abundant brachyuran crab, after portunid crabs of genus Callinectes Stimpson, 1860 (Mantelatto \& Fransozo 2000, Braga et al. 2005, Bertini et al. 2010). Even though it is not a commercial species, it is frequently captured in the same areas of the shrimp fisheries of Xiphopenaeus kroyeri (Heller, 1862), Farfantepenaeus paulensis (Pérez-Farfante, 1967), Farfantepenaeus brasiliensis (Latreille, 1817), and Penaeus schmitti Burkenroad, 1936 (see Bertini et al. 2010 and Mantelatto et al. 2016 for details). Some authors reported that $H$. pudibundus is one of the most commonly bycatch species of fisheries targeting the shrimp X. kroyeri (Heller, 1862) (Fransozo et al. 2016, Mantelatto et al. 2016). However, its abundance is not affected by these fisheries because the crabs are returned to the sea while still alive.

Although H. pudibundus is an important species in the food webs of unconsolidated sediments along the infralittoral (Mantelatto \& Petracco 1997), most previous studies focused on biological aspects, including larval and juvenile development in the laboratory and from field samplings (Rieger \& Hebling 1993, Hebling \& Rieger 2003, Negreiros-Fransozo et al. 2008), population structure (Mantelatto et al. 1995b, Fracasso \& Branco 2005, Klôh \& Di Beneditto 2010, Lima et al. 2014a), morphometry (Mantelatto \& Fransozo 1992, 1994), feeding strategies (Mantelatto \& Petracco 1997), reproductive biology (Reigada \& Negreiros-Fransozo 1999, 2000, Lima et al. 2014b), and growth and mortality (Keunecke et al. 2007). A few studies focused on H. pudibundus distribution (Mantelatto et al. 1995a, Lima et al. 2014a), but none of them included areas of $20 \mathrm{~m}$ in depth or deeper.

Aiming to test the hypothesis of differential ocupation, the temporal and bathymetric distribution of $H$. pudibundus were evaluated and correlated with environmental factors (bottom and surface water temperature and salinity, and sediment texture and organic matter) in Ubatuba region. This region is ideal for ecological studies using benthonic populations as a baseline to understand distribution patterns and ecological relationships. Once the profile of an abundant species is known, it can be used in future monitoring and in the evaluation of possible natural/anthropic impacts, as well as serve as comparative parameter for other similar decapod populations.

\section{Material and Methods}

\section{Study area}

The northern coast of São Paulo, in the southeast of Brazil, and specially the Ubatuba region, encompasses a variety of environments such as pristine islands, bays, inlets, sandy and rocky beaches, mangroves, estuaries, and coastal rivers. Due to this spatial heterogeneity, it has a high biodiversity of decapod crustaceans (Mantelatto et al. 2018). The sediment in this region is composed by fine or very fine sand and silt and clay, given the low water movement within the area and among the regions (Mahiques et al. 1998).

This region is under the influence of three water masses: Coastal Water $\left(\mathrm{CW}=\right.$ temperature $>20^{\circ} \mathrm{C}$; salinity $\left.<36\right)$, Tropical Water $(\mathrm{TW}$ $=$ temperature $>20^{\circ} \mathrm{C}$; salinity $>36$ ), and South Atlantic Central Water $\left(\mathrm{SACW}=\right.$ temperature $<18^{\circ} \mathrm{C}$; salinity $<36$ ) (Castro-Filho et al. 1987; Odebrecht \& Castello 2001; De Léo \& Pires-Vanin 2006). During late spring and early summer, the SACW penetrates the bottom layer of the coastal region and forms a thermocline over the inner shelf at depths of 10-15 m (Castro-Filho et al. 1987). During winter, the SACW retreats to the shelf break and is replaced by the $\mathrm{CW}$. As a result, no stratification is present over the inner shelf during the winter months (Pires 1992; Pires-Vanin \& Matsuura 1993).

\section{Data collection}

Samplings were done monthly in Ubatuba $\left(23^{\circ} 26^{\prime} 75^{\prime \prime} \mathrm{S}\right.$; $\left.44^{\circ} 59^{\prime} 00^{\prime \prime} \mathrm{W}\right)$ with a fishing boat equipped with two double rig nets, from January to December 2000. A total of nine transects ( $2 \mathrm{~km}$ each) were stablished and trawled over a 30 -min period covering a sampling area of about $18000 \mathrm{~m}^{2}$. Samplings comprised depths of 2, 5, 10, and 15 $\mathrm{m}$ (in the internal area of the bay), and 20, 25, 30, 35 and $40 \mathrm{~m}$ (in the external area) (Figure 1). An ecobathymeter coupled with a GPS was used to record depth at sampling sites. For the analysis of environmental factors, sediment and surface and bottom water samples were taken from each transect before trawling. Water was collected with a Nansen 


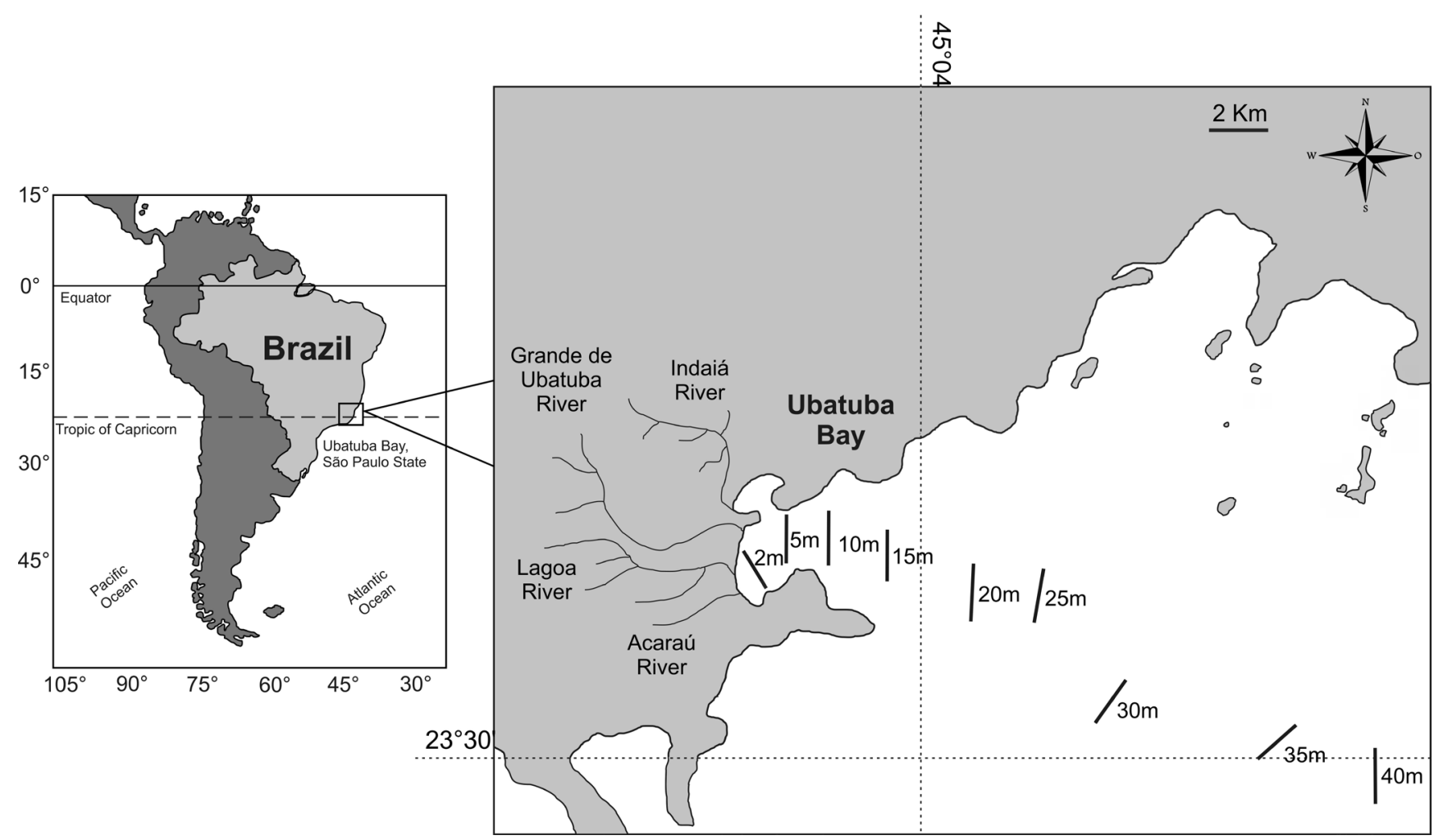

Figure 1. Map of South America. In detail, the Ubatuba coast in São Paulo, Brazil, indicating the location and depth of the transects. (Modified from Lima et al. 2014c).

bottle to obtain temperature and salinity, measurements with the ad of a mercury thermometer $\left({ }^{\circ} \mathrm{C}\right)$ and salinity and an optical refractometer (\%), respectively.

The method used to measure the texture of the sediment was similar to that described by Hakanson \& Jansson (1983) and Tucker (1988). Sediment samples were collected at each transect with a Van Veen grab $\left(0.063 \mathrm{~m}^{2}\right)$ for sediment grain size composition and organic matter content determination. Samples were transported to the laboratory and oven-dried at $70{ }^{\circ} \mathrm{C}$ for $72 \mathrm{~h}$. To analyze the grain size distribution, two $50 \mathrm{~g}$ subsamples were treated with $250 \mathrm{ml}$ of $\mathrm{NaOH}$ solution $\left(0.2 \mathrm{~mol} \mathrm{l}^{-1}\right)$, stirred for $5 \mathrm{~min}$ to release silt and clay particles, and rinsed over a $0.063 \mathrm{~mm}$ sieve. The grain size was classified according to the Wentworth (1922) scale: $>2 \mathrm{~mm}$ (gravel), 1.0-2.0 mm (very coarse sand), $0.5-1.0 \mathrm{~mm}$ (coarse sand), $0.25-0.5 \mathrm{~mm}$ (medium sand), $0.125-0.25 \mathrm{~mm}$ (fine sand), $0.125-0.063 \mathrm{~mm}$ (very fine sand). Smaller particles were classified as silt and clay.

Grain diameter was expressed in phi $(\varphi)$ values (were calculated from the formula $\mathrm{phi}=-\log 2 \mathrm{~d}$, where $\mathrm{d}=$ grain diameter in $\mathrm{mm}$ ), and the following classes were obtained: $-2 \leq$ phi $<-1$ (gravel), $-1 \leq$ phi $<$ 0 (very coarse sand), $0 \leq$ phi $<1$ (coarse sand), $1 \leq$ phi $<2$ (medium sand), $2 \leq$ phi $<3$ (fine sand), $3 \leq$ phi $<4$ (very fine sand), and phi $\geq 4$ (silt and clay). From the cumulative distribution curves of these classes to, the $16^{\text {th }}, 50^{\text {th }}$ and $84^{\text {th }}$ percentiles were extracted and the mean diameter (md) was calculated with the formula: $\mathrm{MD}=\left(\mathrm{phi}_{16}+\mathrm{phi}_{50}\right.$ + phi ${ }_{84}$ )/3 (Suguio 1973). The three most quantitatively important sediments were defined according to Magliocca \& Kutner (1965): Class A corresponds to sediments in which medium sand (MS), coarse sand (CS), very coarse sand (VCS) and gravel (G); in class B, fine sand (FS) and very fine sand (VFS) and class $\mathrm{C}$ with silt and clay $(\mathrm{S}+\mathrm{C})$. Using these three classes, further groups were established according to the combination of granulometric fractions in several proportions: $\mathrm{PA}=$ $(\mathrm{MS}+\mathrm{CS}+\mathrm{VCS}+\mathrm{G})>70 \%$; $\mathrm{PAB}=$ prevalence of $\mathrm{A}$ over $\mathrm{B}(\mathrm{FS}+\mathrm{VFS})$; $\mathrm{PAC}=$ prevalence of $\mathrm{A}$ over $\mathrm{C}(\mathrm{S}+\mathrm{C}) ; \mathrm{PB}=(\mathrm{FS}+\mathrm{VFS})>70 \%$; $\mathrm{PBA}=$ prevalence of $\mathrm{B}$ over $\mathrm{A} ; \mathrm{PBC}=$ prevalence of $\mathrm{B}$ over $\mathrm{C} ; \mathrm{PC}=(\mathrm{S}+\mathrm{C})>$ $70 \% ; \mathrm{PCA}=$ prevalence of $\mathrm{C}$ over $\mathrm{A} ; \mathrm{PCB}=$ prevalence of $\mathrm{C}$ over $\mathrm{B}$. For organic matter content determination, we put $10 \mathrm{~g}$ subsamples in porcelain containers, previously individually identified and weighed. Incinerated in an oven $\left(500{ }^{\circ} \mathrm{C}\right.$ for 3 hours $)$ and weighed again. The difference between the initial and final weigh indicated the organic matter content of each sample, which was expresses as a proportion of the initial weight (Hieri et al. 2001). The obtained data were grouped by season of the year as follows: January-March = summer, AprilJune $=$ autumn, July-September $=$ winter, and October-December = spring. The specimens of Hepatus pudibundus (Figure 2) were identified following Melo (1996) and sorted by sex, based on abdominal morphological features (male $=$ triangular-shaped abdomen; female = round-shaped abdomen), and number of pleopods (males = two pairs; females $=$ four pairs).

\section{Data analysis}

Prior the analyses the data were tested for normality (Shapiro-Wilk's test) and homoscedasticity (Levene's test) (Zar 1999). Abundance, bottom and surface temperature and bottom salinity were compared between months and transects using the Friedman test $(\alpha=0.05)$. Moreover, the phi-values were compared between transects also using the Friedman test $(\alpha=0.05)$ (Zar 1999). We used a Redundancy Analysis (RDA) to detect possible relationships between the abundance of $H$. pudibundus and the environmental variables. This analysis requires the 


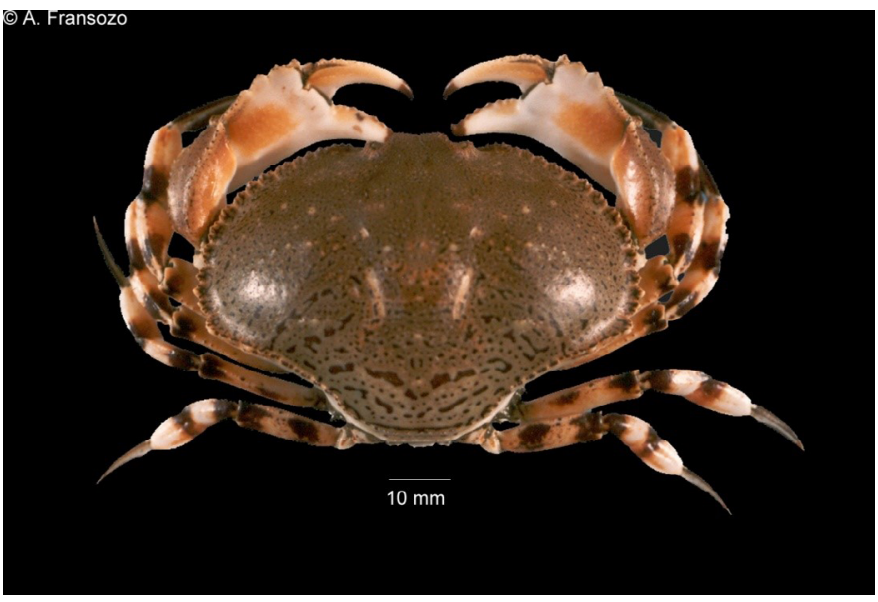

Figure 2. Hepatus pudibundus (Herbst, 1785). Adult male (carapace width $72.7 \mathrm{~mm})$.

existence of two dependent variables, at least. Thus, we grouped the individuals into males (M) and females (F). The RDA produces final coordination scores that summarize the linear relationship between the explanatory and response variables. Only environmental variables with scores higher than 0.4 and lower than -0.4 were considered as biologically significant (Rakocinski et al. 1996). This analysis was performed using the Vegan (Oksanen et al. 2012) package for R ( R Development Core Team, 2012).

\section{Results}

Along the year there were significant differences between surface (Friedman test $\mathrm{Fr}=93.4 ; \mathrm{p}=0.0001$ ) and bottom water temperature (Friedman test $\mathrm{Fr}=51.84 ; \mathrm{p}=0.0001$ ). Moreover, a thermocline was seen from January through April (Figure 3A, B). Bottom temperatures decreased gradually with the increase in depth (Friedman test $\mathrm{Fr}=54.8$; $\mathrm{p}=0.0001)$, whereas surface temperature was homogeneous $(\mathrm{Fr}=13.4$; $\mathrm{p}=0.0974$ ) (Figure 3C, D). Spatially, bottom salinity was lower at 2 $\mathrm{m}(33.1 \%)$ and higher at $40 \mathrm{~m}$ of depth $(35.4 \%)$ (Friedman test; $\mathrm{Fr}=$ 20.4; $\mathrm{p}=0.0089$ ) (Figure 4).

Phi-values differed between transects $(\mathrm{Fr}=71.68 ; \mathrm{p}=0.0001)$. The highest proportions of sediment silt and clay occurred in association with high organic matter content in the $5-10 \mathrm{~m}$ deep transects. Below $10 \mathrm{~m}$ of depth, these proportions decreased. Most transects were characterized by a high amount of silt and clay, except the transects 30 and $35 \mathrm{~m}$ deep, which had lower phi-values (Figure 5), i.e., a coarser sediment grain size composition.

In total, 1808 crabs were collected. There were no significant differences in abundance between months (Friedman test; $\mathrm{Fr}=11.4 ; \mathrm{p}$ $=0.4102)$ or seasons (Friedman test; $\mathrm{Fr}=5.9 ; \mathrm{p}=0.1166)$ (Table 1). There was, however, a significant variation in abundance between transects (Friedman test; $\mathrm{Fr}=34.0 ; \mathrm{p}=0.0001$ ) (Table 1). Higher $H$. pudibundus abundances were associated with bottom temperatures of $19-22^{\circ} \mathrm{C}$, salinities of $38-40 \%$, sediment phi of 3.08-4.48, and organic matter content of $2.90-7.15 \%$ (Figure 6). The highest abundance was recorded in winter at $15 \mathrm{~m}$ of depth, and the lowest in spring/summer at 30-40 m of depth. Nonetheless, the species showed a wide distribution, being found in all seasons. In spring and summer, the crabs were more abundant in the transects 10-20 $\mathrm{m}$ deep where the organic matter content was higher (Figure 7). As can be seen in the RDA Axis 1 (94.4\%), the abundance of males and females was correlated with sediment phi and organic matter content, and these two factors were the most important determinants of $H$. pudibundus distribution (Table 2).

\section{Discussion}

Hepatus pudibundus showed a wide spatio-temporal distribution but its abundance varied according to variation in environmental factors. In Ubatuba there are several bays and inlets which form a semi-enclosed region water circulation difficult (Mahiques 1995). These characteristics favor the entrapment of urban sewage coming from the Northern coast of São Paulo, which increases the food availability to detritivores and filter-feeders (Negreiros-Fransozo et al. 1991). Also, environments with a high content of organic matter favor the establishment and development of a variety of organisms (Negreiros-Fransozo et al. 1991). Therefore, the establishment of this species may be due to the good conditions in this place, since this species is an opportunistic predator (Mantelatto \& Petracco 1997).

According to Fransozo et al. (2012), the influx of this nutrient-rich cold-water mass may influence the composition and abundance of decapod crustaceans. Although temperature was not a significant factor, the decrease in $H$. pudibundus abundance during spring and summer may have been related to the influx of SACW, which caused a seasonal migration to shallower, warmer areas, where the organic matter increases in this period. During summer, and with the entrance of SACW, abundant salpids (Tunicata, Salpidae), among other diverse invertebrate groups, feed on phyto- and nanoplankton, and their decomposition and defecation form fecal pellets that are incorporated into the sediment as organic matter and benefit the benthos (Pires-Vanin et al. 1993).

The higher abundance in deeper areas during autumn and winter may be explained by the action of currents and high amplitude waves, which swirls the sediment and suspends the abundant detritivore and filter-feeding macrofauna (Pires et al. 1993) that are food sources for many decapods, induding H. pudibundus. Moreover, as in these seasons the temperature becomes more homogeneous, as well as $H$. pudibundus, other carnivorous species are more predominant in the inner platform, such as, Callinectes ornatus Ordway, 1863; Achelous spinimanus (Latrelle, 1819) and Libinia spinosa Guérin, 1832 (Pires-Vanin et al. 1993, Petti et al. 1996).

The low abundance seen in the very shallow transects ( $2 \mathrm{~m}$ deep) may have been caused by the freshwater influx coming from four rivers that form estuaries in Ubatuba and decrease salinity (Mantelatto et al. 1995a). The same author also found a lower abundance near estuaries in Fortaleza Bay, in the northern coast of São Paulo. Many authors consider sediment texture and organic matter content as the causes of abundance fluctuations of benthonic species (Ishikawa 1989, Fransozo et al. 1992, Costa et al. 2005). In our study, $72 \%$ of the individuals were captured between 10-25 m of depth. The sediment in these transects was composed mainly by silt and clay, and fine and very fine sand, which usually to have a higher percentage of organic matter (Castilho et al., 2008). Therefore, these areas are favorable for $H$. pudibundus, offering food and shelter for a species that buries into the sediment (Mantelatto et al. 1995a). Moreover, Mantelatto \& Petracco (1997), which investigated 

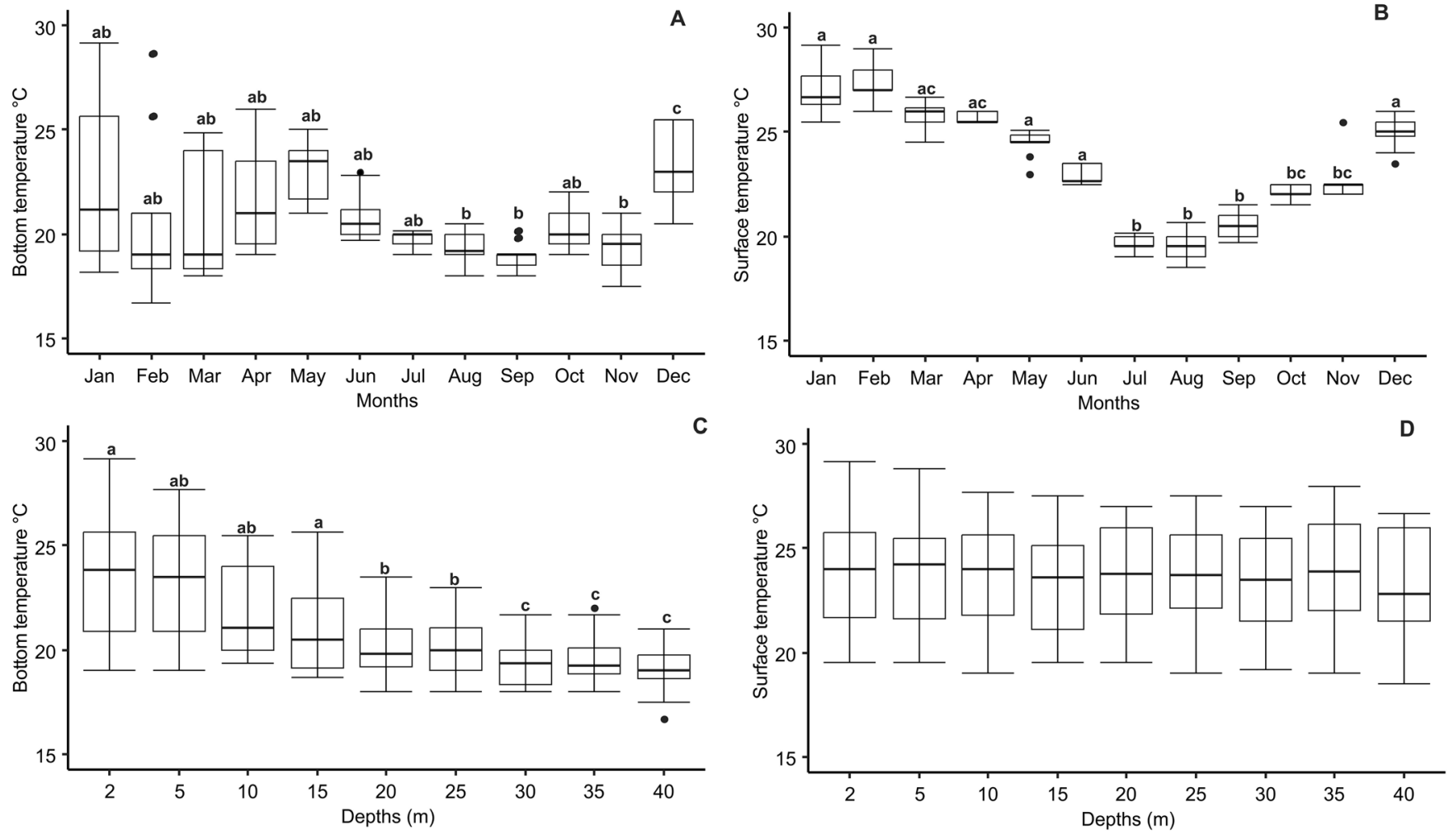

Figure 3. Boxplots of bottom (BT) and surface (ST) temperature (median, minimum and maximum) per month (A and B) and per transect (C and D) in January-December 2000, in the region of Ubatuba, São Paulo, Brazil (Friedman Test; different letters indicate a statistically significant difference).

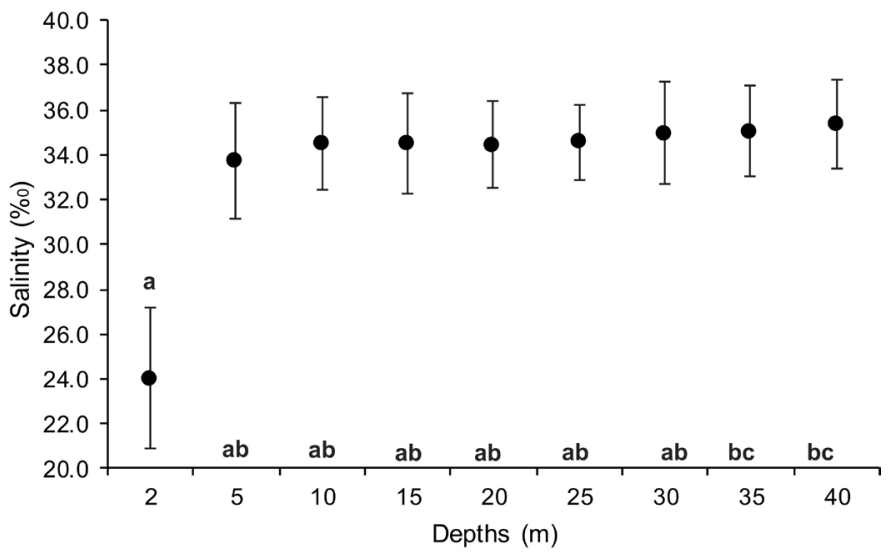

Figure 4. Variation in mean salinity according to depth, Ubatuba, 2000.

the diet of H. pudibundus, concluded that this species is an opportunistic predator which has a large variety of preys, including mollusks, annelids, and foraminiferans, which are more abundant in finer sediments.

In our study there was a positive correlation between the abundance and phi (sediment texture) and organic matter content, corroborating the findings in close areas, as made by Mantelatto et al. (1995a) in Fortaleza Bay, where H. pudibundus was also more abundant in regions with higher organic matter content. On the other hand, Lima et al. (2014a) found no significant relationship, probably because their sampling was restricted to depths of $20 \mathrm{~m}$ or less. Nonetheless, they found the higher number of individuals in Mar Virado Bay, in which the silt and clay fraction

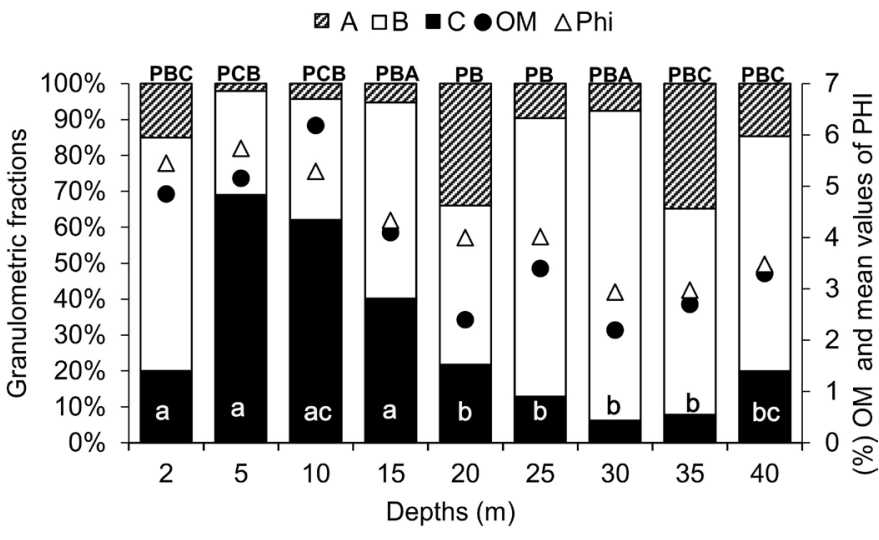

Figure 5. Granulometric fractions, organic matter content $(\% \mathrm{OM})$, and sediment mean grain size (Phi) of each transect. Grain-size classes (\%) are: class A (sand, coarse sand, very coarse sand, and gravel), class B (fine sand and very fine sand), and class $\mathrm{C}$ (silt and clay).

predominates. Like H. pudibundus, other species of crabs that are buried such as Arenaeus cribrarius (Lamarck 1818) by Pinheiro et al. (1996), Callinectes danae Smith, 1869 by Chacur \& Negreiros-Fransozo (2001), and $L$. spinosa by Braga et al. (2007), are also most frequently found in areas with finer sediments along the Northern coast of São Paulo.

According to McNaughton \& Wolf(1970), the dominance of certain species may be explained by two non exclusive hypotheses. The first postulates that dominant species are generalist and can tolerate varied environmental conditions, and the second one says they are specialists 
Table 1. Hepatus pudibundus (Herbst 1785). Number of individuals per month and sampling station captured from January until December 2000 (2, 5, 10,15 (internal area), 20, 25, 30, 35 and $40 \mathrm{~m}$ (external area)). (Results of Friedman $=$ Fr test, different letters indicate a statistical significant difference $(\mathrm{p}<0.05)$.

\begin{tabular}{|c|c|c|c|c|c|c|c|c|c|c|c|c|}
\hline \multirow{2}{*}{ Season } & \multirow{2}{*}{ Months } & \multicolumn{4}{|c|}{ Internal area } & \multicolumn{5}{|c|}{ External area } & \multicolumn{2}{|c|}{ Total } \\
\hline & & $2 m$ & $5 \mathrm{~m}$ & $10 \mathrm{~m}$ & $15 \mathrm{~m}$ & $20 \mathrm{~m}$ & $25 \mathrm{~m}$ & $30 \mathrm{~m}$ & $35 m$ & $40 m$ & Month & Season \\
\hline \multirow{2}{*}{ Summer } & Jan & 0 & 0 & 47 & 39 & 7 & 0 & 0 & 1 & 0 & 94 & \\
\hline & Mar & 3 & 11 & 94 & 38 & 5 & 4 & 2 & 0 & 0 & 157 & \\
\hline \multirow{2}{*}{ Autumm } & Apr & 0 & 5 & 11 & 30 & 43 & 4 & 43 & 1 & 0 & 137 & \\
\hline & Jun & 0 & 4 & 0 & 78 & 3 & 1 & 0 & 35 & 0 & 121 & \\
\hline \multirow{3}{*}{ Winter } & Jul & 5 & 14 & 15 & 85 & 2 & 66 & 1 & 3 & 64 & 255 & \\
\hline & Aug & 0 & 34 & 7 & 23 & 38 & 65 & 3 & 7 & 0 & 177 & 549 \\
\hline & Sep & 15 & 2 & 8 & 84 & 0 & 8 & 0 & 0 & 0 & 117 & \\
\hline Spring & Oct & 3 & 9 & 33 & 111 & 73 & 23 & 0 & 1 & 0 & 253 & \\
\hline Fr Test & & (A) & $(\mathrm{AB})$ & $(\mathrm{AB})$ & (B) & $(\mathrm{AB})$ & $(\mathrm{AB})$ & $(\mathrm{A})$ & (A) & $(\mathrm{A})$ & & \\
\hline
\end{tabular}
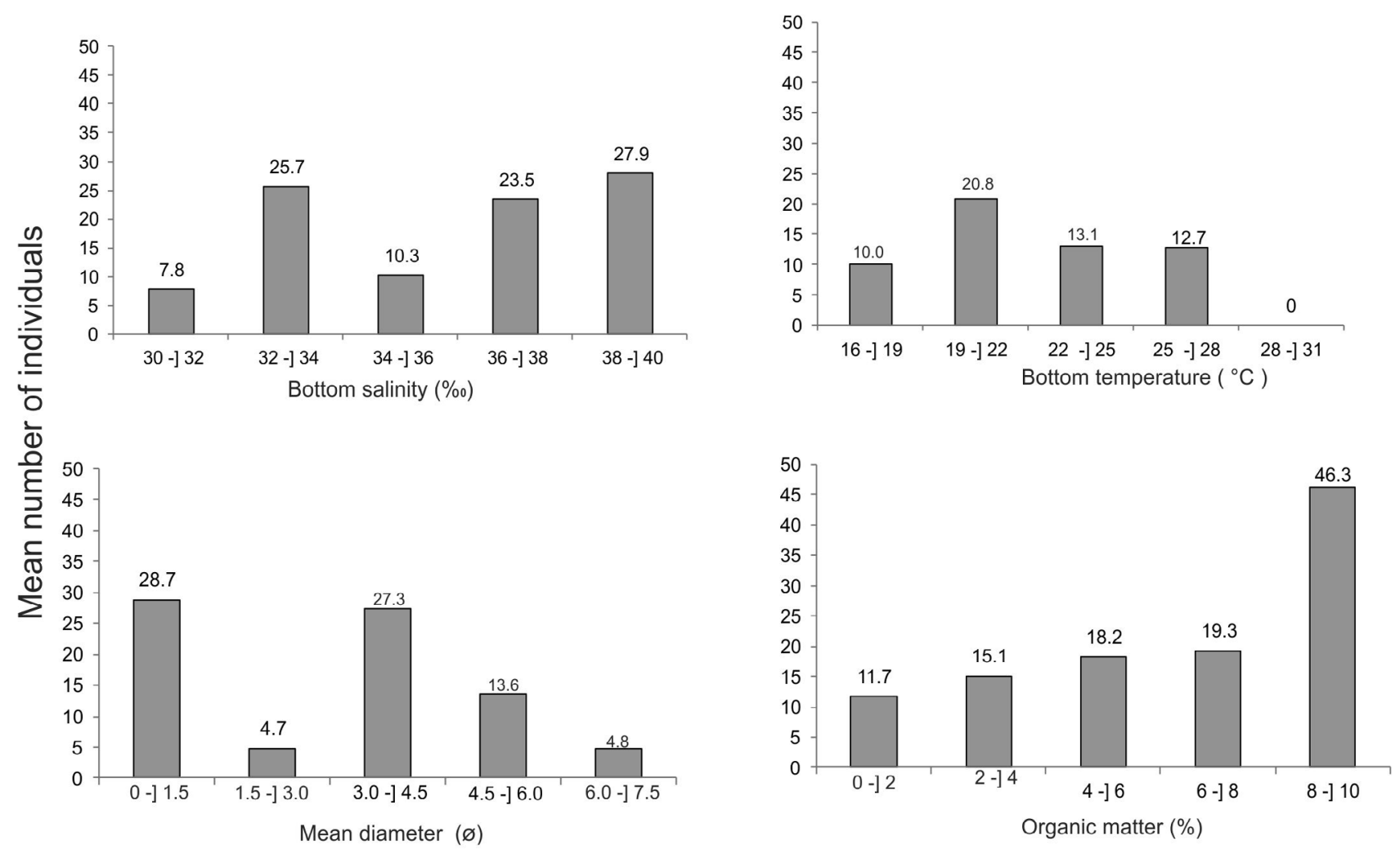

Figure 6. Hepatus pudibundus (Herbst, 1785). Mean number of individuals per trawl for each class of environmental factors in Ubatuba, State of São Paulo, Southeastern Brazil (January-December 2000).

and adapted to a narrower set of conditions. In general, areas deeper than $20 \mathrm{~m}$ in Ubatuba suffer a high influence of sea currents, resulting in more heterogeneous sediments with predominance of fine and very fine sand, and low organic matter content (Furtado \& Mahiques 1990). As H. pudibundus is a burrowing species, coarse sandy sediments with dendritic fragments may hinder its establishment (Bertini \& Fransozo
2004) thus, sheltered bays with a heterogeneous substrate may be unfavorable to this species (Lima et al. 2014a).

Our results strong support the hypothesis that the distribution of H. pudibundus is modulated by abiotic factors, especially those related to the sediment. It's worth mentioning that Ubatuba has been under an intense urbanization process, which will likely affect the local marine 


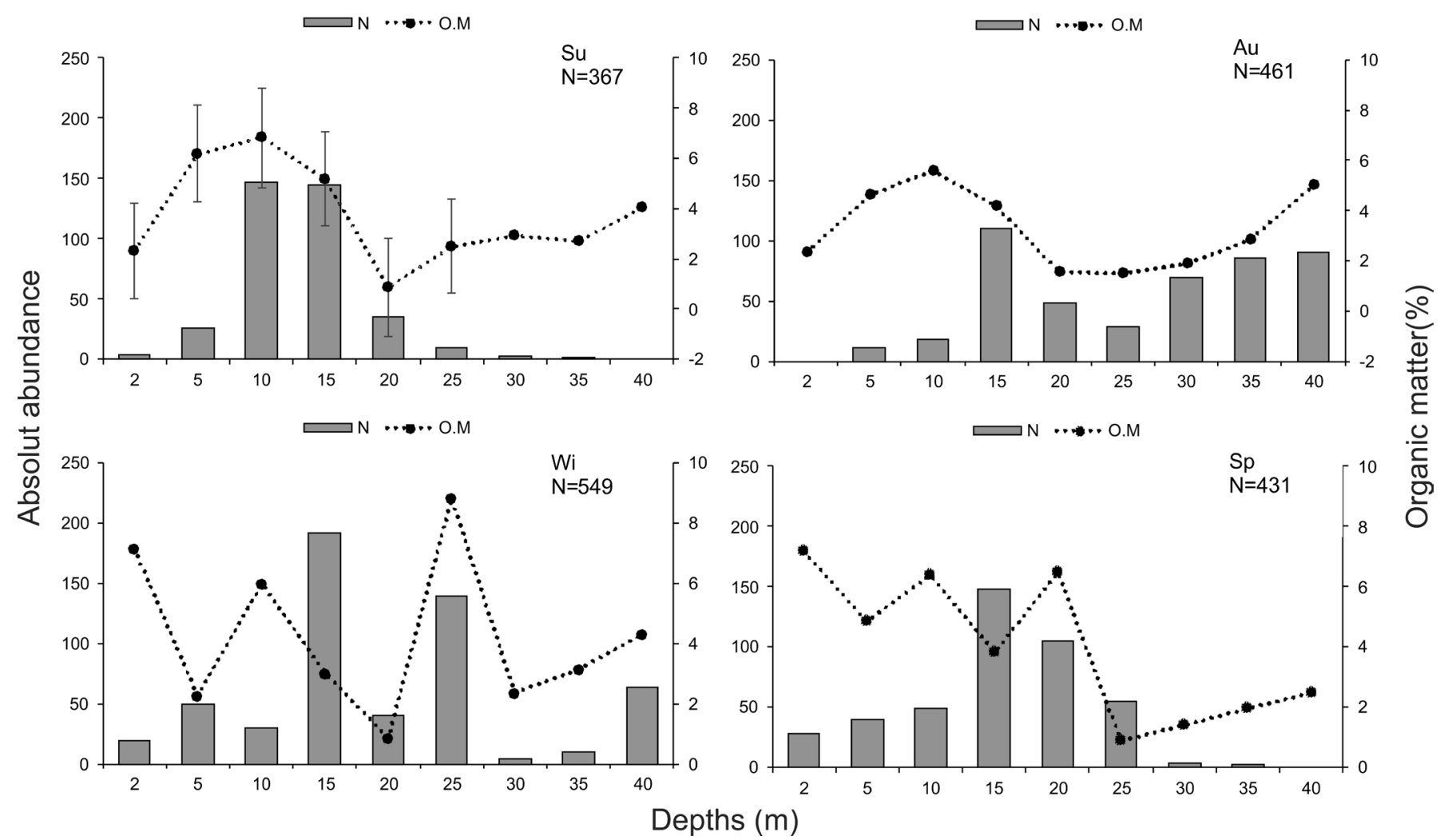

Figure 7. Hepatus pudibundus (Herbst, 1785). Seasonal distribution according to depth and organic matter content. Bars indicate the number of crabs and dots indicate the organic matter content $(\mathrm{N}=$ number of crabs, $\mathrm{OM}=$ Organic matter, $\mathrm{Su}=$ Summer, $\mathrm{Au}=$ Autumn, $\mathrm{Wi}=\mathrm{Winter}, \mathrm{Sp}=\mathrm{Spring})$.

Table 2. Hepatus pudibundus (Herbst 1785). Redundancy Analysis (RDA) showing the relationship between demographic groups and environmental variables, in Ubatuba Bay, Sao Paulo, Brazil.

\begin{tabular}{lcc}
\hline & Axis 1 & Axis 2 \\
\hline Eigenvalue & 0.020 & 0 \\
Proportion Explained & 0.944 & 0.056 \\
Cumulative Proportion & 0.944 & 1 \\
\hline Abundance of individuals & & \\
\hline Males & -0.329 & -0.091 \\
Females & -0.376 & 0.079 \\
\hline Environmental variables & & \\
\hline Botton temperature (BT) & 0.105 & -0.132 \\
Botton salinity (BS) & -0.213 & -0.638 \\
Organic Matter (OM) & $\mathbf{- 0 . 8 7 2}$ & 0.237 \\
Phi & $\mathbf{- 0 . 4 4 0}$ & -0.475 \\
\hline
\end{tabular}

* Values in bold indicate the variables considered as biologically significant (i. e. $>0.4$ and $<-0.4$ ) Rakocinski et al. (1996).

diversity in different ways. Thus, only through comprehensive and rigorous studies on key populations and communities of commercial and/or ecological importance it will be possible to stablish conservation strategies and protected areas. Also, abundant species could be used as bioindicators, to ensure that natural resources are used in a sustainable way, and that the natural biodiversity is being protected against natural and anthropic actions.

\section{Acknowledgements}

We are grateful to the Fundacão de Amparo à Pesquisa do Estado de São Paulo (FAPESP) for providing financial support (\# 94/4878-8, \# 97/12108-6, \# 97/12106-3, \# 97/12107/0 and \# 98/3134-6). We are also thankful to our NEBECC co-workers for their help during field work. All samplings have been conducted complying with current applicable state and federal laws. FLM and AF are grateful to Conselho Nacional de Pesquisa e Desenvolvimento Tecnológico - CNPq for ongoing Research fellowships (PQ 304968/2014-5 and 300400/86-1, respectively). We thank anonymous reviewers for their suggestions that helped to improve the quality of this paper during the revision process.

\section{Author Contributions}

Substantial contribution in the concept and design of the study: All authors.

Adilson Fransozo: Contribution to data collection.

Veronica Pereira Bernardes, Fernando Luis Mantelatto, Thiago Elias da Silva, Aline Nonato de Sousa, Camila Hipólito Bernardo and Adilson Fransozo: Contribution to data analysis and interpretation.

Veronica Pereira Bernardes, Fernando Luis Mantelatto, Thiago Elias da Silva, Aline Nonato de Sousa, Camila Hipólito Bernardo and Adilson Fransozo: Contribution to manuscript preparation.

Veronica Pereira Bernardes, Fernando Luis Mantelatto, Thiago Elias da Silva, Aline Nonato de Sousa, Camila Hipólito Bernardo and Adilson Fransozo: Contribution to critical revision, adding intelectual content. 


\section{Conflicts of interest}

The author(s) declare(s) that they have no conflict of interest related to the publication of this manuscript.

\section{References}

ANDRADE, L.S., ANTUNES, M., LIMA, P.A., FURLAN, M., FRAMESCHI, I.F., \& FRANSOZO, A. 2015. Reproductive features of the swimming crab Callinectes danae (Crustacea, Portunoidea) on the subtropical coast of Brazil: a sampling outside the estuary. Braz. J. Biol. 75(3): 692-702.

BEGON, M., TOWNSEND, C.R. \& HARPER, J.L. 2006. Ecology: from individual to ecosystems. 4 ed. Blackwell Publishing, Malden.

BERNARDES, V.P., SOUSA, A.N., TELES, J.N. \& FRANSOZO, A. 2016. Abundância e distribuição ecológica do caranguejo aranha endêmico Leurocyclus tuberculosus (H. Milne Edwards \& Lucas, 1834) (Crustacea: Decapoda: Majoidea) em diferentes profundidades no litoral norte paulista. Revista Ciência et Praxis. 9(17): 07-16

BERTINI, G. \& FRANSOZO, A. 1999. Spatial and seasonal distribution of Petrochirus diogenes (ANOMURA, DIOGENIDAE) in the Ubatuba bay, São Paulo, Brazil. Iheringia Ser. Zool. 86(1): 145-150.

BERTINI, G. \& FRANSOZO, A. 2004. Biodiversity of brachyuran crabs (Crustacea: Decapoda) from non-consolidated sublittoral bottom on the northern coast of São Paulo State, Brazil. Biodivers. Conserv. 13(12): 2185-2207.

BERTINI, G., FRANSOZO, A. \& NEGREIROS-FRANSOZO, M.L. 2010. Brachyuran soft-bottom assemblage from marine shallow waters in the southeastern Brazilian littoral. Mar. Biodivers. 40(4): 277-291.

BRAGA, A.A., FRANSOZO, A., BERTINI, G., FUMIS, P.B. 2005. Composition and abundance of the crabs (Decapoda, Brachyura) off Ubatuba and Caraguatatuba, northern coast of São Paulo, Brazil. Biota Neotrop. 5(2):134. dx.doi.org/10.1590/S1676-06032005000300004

BRAGA, A.A., FRANSOZO, A., BERTINI, G. \& FUMIS, P.B. 2007. Bathymetric distribution and recruitment of the spider crab Libinia spinosa H. Milne Edwards 1834 in the Ubatuba and Caraguatatuba regions, northern coast of São Paulo, Brazil (Crustacea, Brachyura, Majoidea, Pisidae). Senckenberg Biol. 87(1): 7-16.

BUCHANAN, B.A., STONER, A.W. 1988. Distributional patterns of blue crabs (Callinectes sp.) in a tropical estuarine lagoon. Estuaries 11(4): 231-239.

BURONE, L., \& PIRES-VANIN, A.M.S. 2006. Foraminiferal assemblages in the Ubatuba Bay, south-eastern Brazilian Coast. Sci. Mar. 70(2): 203-217.

CASTILHO, A.L., FURLAN, M., COSTA, R.C. \& FRANSOZO, V. 2008 Abundance and temporal-spatial distribution of the rock shrimp Sycionia dorsalis Kingsley, 1878 (Decapoda, Penaeoidea) from the northern coast of São Paulo state, Brazil. Senckenbergiana, 38(1): 75-83p

CASTRO-FILHO, B.M., MIRANDA, L.B. \& MYAO, S.Y. 1987. Condições hidrográficas na plataforma continental ao largo de Ubatuba: variações sazonais e em média escala. Bol. Inst. Oceanogr. 35(2): 135151.

CHACUR, M.M. \& NEGREIROS-FRANSOZO, M.L. 2001. Spatial and seasonal distribution of Callinectes danae (Decapoda, Portunidae) in Ubatuba Bay, São Paulo, Brazil. J. Crustacean Biol. 21(2): 414-425.

COSTA, R.C., FRANSOZO, A., CASTILHO, A.L., \& FREIRE, F.A. 2005. Annual, seasonal and spatial variation of abundance of the shrimp Artemesia longinaris (Decapoda: Penaeoidea) in south-eastern Brazil. J. Mar. Biol. Assoc. U. K. 85(1): 107-112.

DE LÉO, F.C. \& PIRES-VANIN, A.M.S. 2006. Benthic megafauna communities under the influence of the South Atlantic Central Water intrusion onto the Brazilian SE shelf: a comparison between an upwelling and a non-upwelling ecosystem. J. Mar. Syst. 60(3): 268-284.

FRACASSO, H.A.A. \& BRANCO, J.O. 2005. Population structure of Hepatus pudibundus (Herbst) in the Armação do Itapocoroy, Santa Catarina, Brazil Rev. Bras. Zool. 22(2): 342-348.
FRANSOZO, A., FURLAN, M., FRANSOZO, V., BERTINI, G., COSTA, R.C. \& FERNANDES-GÓES, L.C. 2012. Diversity of decapod crustaceans at the interface of unconsolidated seabed areas and rocky shores in tropical/ subtropical Brazil. Afr. J. Mar. Sci. 34(3): 361-371.

FRANSOZO, A., NEGREIROS-FRANSOZO, M.L., MANTELATTO, F.L., PINHEIRO, M.A.A. \& SANTOS, S. 1992. Composição e distribuição dos Brachyura (Crustacea, Decapoda) do sublitoral não consolidado na Enseada da Fortaleza, Ubatuba (SP). Rev. Bras. Biol. 52(4): 667-675

FRANSOZO, A., SOUSA, A.N., RODRIGUES, G.F.B., TELLES, J.N., FRANSOZO, V., NEGREIROS-FRANSOZO, M.L. 2016. Decapod crustaceans captured along with the sea-bob shrimp fisheries on nonconsolidated sublitoral From Northern Coast of São Paulo, Brazil. Bol. Inst. Pesca. 42(2): 369-386.

FURTADO, V.V. \& MAHIQUES, M.M. 1990. Distribuição de sedimentos em regiões costeiras e plataforma continental de São Paulo. In Simpósio sobre ecossistemas da costa sul e sudeste brasileira: estrutura, função e manejo. Águas de Lindóia, São Paulo, p. 20-29.

GALLO-JUNIOR, H.; VIANNA, L.P.; POLETTO, C.R.B.; OLIVATO, D. 2011 Análise das políticas de proteção ambiental na área marinha do litoral norte de São Paulo, Brasil. Revista de Geografia da América Central, Número especial EGAL: 1-15.

HAKANSON, L., \& JANSSON, M. 1983. Principles of lake sedimentology. Springer-Verlag. Germany, $315 \mathrm{p}$.

HALL, M.A., ALVERSON, D.L., \& METUZALS, K.I. 2000. Capturas acessórias: problemas e soluções. Bol. Pol. Mar. 41(1-6): 204-219.

HEBLING, N.J. \& RIEGER, P.J. 2003. Desenvolvimento juvenil de Hepatus pudibundus (Herbst, 1875) (Crustacea, Decapoda, Calappidae), em laboratório. Rev. Bras. Zool. 20(3): 531-539.

HEIRI, O., LOTTER, A.F. \& LEMCKE, G. 2001. Loss on ignition as a method for estimating organic and carbonate content in sediments: reproducibility and comparability of results. J. Paleolimn. 25(1): 101-110.

ISHIKAWA, K. 1989. Relationship between bottom characteristics and benthic organisms in the shallow water of Oppa Bay, Miyagi. Mar. Biol. 102(2): 265-273.

KEUNECKE, K.A., D’INCAO, F. \& FONSECA, D.B. 2007. Growth and mortality of Hepatus pudibundus (Herbst 1785) (Crustacea: Calappidae) in south-western Brazil. J. Mar. Biol. Assoc. UK. 87(4): 885-891.

KLÔH, A.S. \& DI BENEDITTO, A.P.M. 2010. Estrutura populacional do siri-baú, Hepatus pudibundus (Herbst 1785) no Norte do Estado do Rio de Janeiro, Sudeste do Brasil. Biota Neotrop. 1(3): 463-467. 10(3):http://www.biotaneotropica.org.br/v10n3/pt/abstract?shortcommunication+bn02510032010

LIMA, P.A., FRANSOZO, V., ANDRADE, L.S., ALMEIDA, A.C., FURLAN, M. \& FRANSOZO, A. 2014a. Distribution and population structure of the flecked box crab Hepatus pudibundus (Herbst 1785) (Decapoda, Brachyura) in the western South Atlantic. Mar. Biol. Res. 10(6): 589-600.

LIMA, P.A., BERTINI, G., FRANSOZO, V., GREGATI, R.A., CORRÊA FERNANDES GÓES, L. \& CASTILHO, A.L. 2014b. Reproductive biology of Hepatus pudibundus (Crustacea: Brachyura), the most abundant crab on the southeastern Brazilian coast. Biologia. 69(2): 219-22.

LIMA, P.A., ANDRADE, L.S., ALENCAR, C.E.R.D., PEREIRA, R.T., TEIXEIRA, G.M., FRANSOZO, A., 2014c. Two species of swimming crabs of the genus Achelous (Crustacea, Brachyura): environmental requirements determining the niche. Hydrobiologia 727(1): 197-207.

MAGLIOCCA, A. \& KUTNER, A.S. 1965. Sedimentos de fundo da Enseada do Flamengo, Ubatuba, SP. Contrib. Inst. Oceanogr. 198: 1-15.

MAHIQUES, M.M. 1995. Dinâmica sedimentar atual nas enseadas da região de Ubatuba, Estado de São Paulo. Bol. Inst. Oceanogr. 43(2):111-122.

MAHIQUES, M.M., TESSLER, M. G., \& FURTADO, V. V. 1998. Characterization of energy gradient in enclosed bays of Ubatuba region, south-eastern Brazil. Estuar. Coast Shelf Sci. 47(4): 431-446. 
MANTELATTO, F.L., BERNARDO, C.H., SILVA, T.E., BERNARDES, V.P., COBO, V.J. \& FRANSOZO, A. 2016. Composição e distribuição de crustáceos decápodes associados à pesca do camarão-sete-barbas Xiphopenaeus kroyeri (Heller, 1862) no litoral norte do estado de São Paulo. Bol. Inst. Pesca 42(2): 307-326.

MANTELATTO, F.L. \& FRANSOZO, A. 1992. Relação peso/largura da carapaça no caranguejo Hepatus pudibundus (Herbst,1785) (Crustacea, Decapoda, Calappidae) na região de Ubatuba, SP, Brasil. Braz. Arch. Biol. Technol. 35(4): 719-724.

MANTELATTO, F.L. \& FRANSOZO, A. 1994. Crescimento relativo e dimorfismo sexual de Hepatus pudibundus (Herbst, 1785) (Decapoda, Brachyura) no litoral paulista. Pap. Avulsos Zool. 39(4): 33-48.

MANTELATTO, F.L. \& FRANSOZO, A. 2000. Brachyuran community in Ubatuba Bay, northern coast of São Paulo State, Brazil. J. Shellfish Res. 19(2): 701-709.

MANTELATTO, F.L., FRANSOZO, A. \& NEGREIROS-FRANSOZO, M.L. 1995a. Distribuição do caranguejo Hepatus pudibundus (Herbst, 1785) (Crustacea, Decapoda, Brachyura) na Enseada de Fortaleza, Ubatuba (SP), Brasil. Bol. Inst. Oceanogr. 43(1): 51-61.

MANTELATTO, F.L., FRANSOZO, A. \& NEGREIROS-FRANSOZO, M.L. 1995b. Population structure of Hepatus pudibundus (Herbst, 1785) (Decapoda, Brachyura, Calappidae) in Fortaleza Bay, Ubatuba (SP), Brazil. Rev. Biol. Trop. 43(1): 259-264.

MANTELATTO, F.L., PETRACCO M. 1997. Natural diet of the crab Hepatus pudibundus (Herbst 1785) (Brachyura: Calappidae) in Fortaleza Bay, Ubatuba (SP), Brazil. J. Crustacean Biol. 17(3): 440-46.

MANTELATTO, F.L., TEROSSI, M., NEGRI, M., BURANELLI, R.C., ROBLES, R., MAGALHÃES, T., TAMBURUS, A.F., ROSSI, M. \& MIYAZAKI, M.J. 2018. DNA sequence database as a tool to identify decapod crustaceans on the São Paulo coastline. Mitochondr. DNA Part A: 29(5): 805-815.

MCNAUGHTON, S.J. \& WOLF, L.L. 1970. Dominance and the niche in ecological systems. Science 167(3915): 131-139.

MELO, G.A.S. 1996. Manual de Identificação dos Brachyura (caranguejos e siris) do litoral brasileiro. Plêiade/FAPESP, São Paulo.

NEGREIROS-FRANSOZO, M. L., FRANSOZO, A., HIROSE, G. L. 2008. The megalopa and early juvenile development of Hepatus pudibundus (Crustacea: Brachyura: Aethroidea) reared from neuston samples. Rev. Bras. Zool. 25(4): 608-616.

NEGREIROS-FRANSOZO, M. L., FRANSOZO, A., PINHEIRO, M. A. A., MANTELATTO, F. L., SANTOS, S. 1991. Caracterização física e química da Enseada de Fortaleza, Ubatuba, SP. Rev. Bras. Geociências 2(2): 114-120.

NG, P.K.L, GUINOT, D. \& DAVIE, P.J.F. 2008. Systema Brachyurorum: Part I. An annotated checklist of extant brachyuran crabs of the world. Raffles Bull. Zool. 17(1): 1-286.
ODEBRECHT, C. \& CASTELLO, J. P. 2001. The convergence ecosystem in the Southwest Atlantic. Seeliger, B. Kjerfve (eds.) In Coastal marine ecosystems of Latin America. pp. 147-165.

OKSANEN, J., BLANCHETT, F.G., KINDT, R., LEGENDRE, P., MINCHIN, P.R., O'HARA, R.B., SIMPSON, G.L., SOLYMOS, P., STEVENS, M.H.M., WAGNER, H. 2012. Vegan: community Ecology Package. R Package 2.0.3.

PETTI, M.A.V., NONATO, E.F. \& PAIVA, P.C.D. 1996. Trophic relationships between polychaetes and brachyuran crabs on the southeastern Brazilian coast. Rev. Bras. Oceanogr. 44(1): 61-67.

PINHEIRO, M.A.A., FRANSOZO, A. \& NEGREIROS-FRANSOZO, M.L. 1996. Distribution patterns of Arenaeus cribrarius (Lamarck, 1818) (Crustacea, Portunidae) in Fortaleza Bay, Ubatuba (SP), Brazil. Rev. Bras. Biol. 56 (4): 705-716.

PIRES, A.M.S. 1992. Structure and dynamics of benthic megafauna on the continental shelf offshore of Ubatuba, southeastern Brazil. Mar. Ecol Progr. Ser. 86: 63-76.

PIRES-VANIN. A.M.S. 1993. A macrofauna bêntica da plataforma continental ao largo de Ubatuba, São Paulo, Brasil. Publção Esp. Inst. Oceanogr. São Paulo. 10:137-158.

PIRES-VANIN, A.M.S. \& MATSUURA, Y. 1993. Estrutura e função do ecossistema de plataforma continental da região de Ubatuba, Estado de São Paulo: uma introdução. Publ. Esp. Inst. Oceanogr. 10: 18.

R DEVELOPMENT CORE TEAM. 2012. R: A language and environment for statistical computing. Vienna: R Foundation for Statistical Computing. http://www.R-project.org.

RAKOCINSKI, C.F., LYCZKOWSKI-SHULTZ, J., RICHARDSON, S.L. 1996. Ichthyoplankton assemblage structure in Mississippi sound as revealed by canonical correspondence analysis. Estuar. Coast Shelf Sci. 43(2): 237-257.

REIGADA, A.L.D. \& NEGREIROS-FRANSOZO, M.L. 1999. Maturidade sexual em Hepatus pudibundus (Decapoda, Brachyura, Calappidae). Iheringia Ser. Zool. 86: 159-164.

REIGADA, A.L.D. \& NEGREIROS-FRANSOZO, M.L. 2000. Reproductive cycle of the Hepatus pudibundus (Herbst, 1785) (Crustacea, Decapoda, Calapidae) in Ubatuba, SP, Brazil. Rev. Bras. Biol. 60(3): 483-491.

RIEGER, P.J. \& HEBLING, N.J. 1993. Desenvolvimento larval de Hepatus pudibundus (Herbst, 1785) (Decapoda, Calappidae) em laboratório. Rev. Bras. Biol. 53(4): 513-528

SUGUIO, K. 1973. Introdução à Sedimentologia. Ed. Edgard Blucher, EDUSP, São Paulo.

TUCKER, M. 1988. Techniques in Sedimentology. Blackwell Scientific Publications. Boston. 394 p.

WENTWORTH C.K. 1922. A scale of grade and class terms for clastic sediments. J. Geol. 30: 377-392.

ZAR, J.H. 1999. Biostatistical analysis. Prentice Hall, New Jersey.

Received: $21 / 03 / 2018$

Revised: $26 / 11 / 2018$

Accepted: 30/11/2018

Published online: 14/01/2019 